\title{
Synergistic anticancer effects of cisplatin and histone deacetylase inhibitors (SAHA and TSA) on cholangiocarcinoma cell lines
}

\author{
MD. ALI ASGAR ${ }^{1}$, GULSIRI SENAWONG $^{2}$, BANCHOB SRIPA $^{3}$ and THANASET SENAWONG ${ }^{1,2}$ \\ ${ }^{1}$ Program in Biological Science, Faculty of Science, ${ }^{2}$ Department of Biochemistry, Faculty of Science, \\ ${ }^{3}$ Department of Pathology, Faculty of Medicine, Khon Kaen University, Khon Kaen 40002, Thailand
}

Received August 30, 2015; Accepted October 23, 2015

DOI: $10.3892 / \mathrm{ijo} .2015 .3240$

\begin{abstract}
Clinical application of cisplatin against cholangiocarcinoma is often associated with resistance and toxicity posing urgent demand for combination therapy. In this study, we evaluated the combined anticancer effect of cisplatin and histone deacetylase inhibitors (HDACIs), suberoylanilide hydroxamic acid (SAHA) and trichostatin A (TSA), on the cholangiocarcinoma KKU-100 and KKU-M214 cell lines. Antiproliferative activity was evaluated using MTT assay. Apoptosis induction and cell cycle arrest were analyzed by flow cytometry. Cell cycle and apoptosis regulating proteins were evaluated by western blot analysis. MTT assay showed that cisplatin, SAHA and TSA dose-dependently reduced the viability of KKU-100 and KKU-M214 cells. The combination of cisplatin and HDACIs exerted significantly more cytotoxicity than the single drugs. Combination indices below 1.0 reflect synergism between cisplatin and HDACIs, leading to positive dose reductions of cisplatin and HDACIs. Cisplatin and HDACIs alone induced G0/G1 phase arrest in KKU-100 cells, but the drug combinations increased sub-G1 percent more than either drug. However, cisplatin and HDACIs alone or in combination increased only the sub-G1 percent in KKU-M214 cells. Annexin V-FITC staining revealed that cisplatin and HDACIs combinations induced more apoptotic cell death of both KKU-100 and KKU-M214 cells than the single drug. In KKU-100 cells, growth inhibition was accompanied by upregulation of p53 and p21 and downregulation of CDK4 and Bcl-2 due to exposure to cisplatin, SAHA and TSA alone or in combination. Moreover, combination of agents exerted higher impacts on protein expression. Single
\end{abstract}

Correspondence to: Dr Thanaset Senawong, Department of Biochemistry, Faculty of Science, Khon Kaen University, Khon Kaen 40002, Thailand

E-mail: sthanaset@kku.ac.th

Abbreviations: HDACIs, histone deacetylase inhibitors; HDAC, histone deacetylase; CCA, cholangiocarcinoma; TSA, trichostatin A; SAHA, suberoylanilide hydroxamic acid; CI, combination index; DRI, dose reduction index

Key words: antiproliferative activity, apoptosis, cell cycle arrest, drug combination, histone deacetylase inhibitors agents or combination did not affect p53 expression, however, combination of cisplatin and HDACIs increased the expression of p21 in KKU-M214 cells. Taken together, cisplatin and HDACIs combination may improve the therapeutic outcome in cholangiocarcinoma patients.

\section{Introduction}

Cholangiocarcinoma (CCA) is a devastating malignancy with poor prognosis and a public health concern in the northeastern Thailand (1). Cisplatin, 5-fluorouracil (5-FU), leucovorin, epirubicin, mitomycin-C and gemcitabine either alone or in combination have been used to treat CCA (2). The clinical application of chemotherapeutic modality with cisplatin is often coupled with adverse side effects, such as nephrotoxicity, neurotoxicity and anemia (3). Another major drawback in applications of cisplatin is the development of resistance by tumors (4). Developing pharmacologically active compounds, termed as chemosensitizers seems to be the unique approach for reversing anticancer chemoresistance and lessening sideeffects as well as toxicity to normal tissues (5). Therefore, CCA patients with chemoresistance and toxicities are urgently in need of a more effective combinative chemotherapy.

CCA evolves from gradual accumulation of genetic and epigenetic changes in regulatory genes in cholangiocytes that lead to the activation of oncogenes and the inactivation or loss of tumor suppressor genes (6). Unlike genetic changes, epigenetic changes are potentially reversible. The reversible histone acetylation and deacetylation are epigenetic phenomena that play crucial roles in the modulation of chromatin topology and the regulation of gene expression. Aberrant expression or mutation of genes, encoding histone acetyltransferase (HAT) or histone deacetylase (HDAC) enzymes has been implicated with carcinogenesis (7). HDACIs induce acetylation of lysine residues of nuclear histones, 'opens up' the chromatin structure, allowing transcription of tumor suppressor and proapoptotic genes. In addition, the open chromatin structures provide additional target sites for DNA-damaging anticancer drugs, such as cisplatin and paraplatin $(8,9)$. HDACIs suppress the proliferation of tumor cells in vitro and in vivo by inducing cell cycle arrest, terminal differentiation and/or apoptosis (7). On the basis of the chemical structures, the natural and synthetic HDACIs reported to date have been classified into four groups including hydroximates, cyclic peptides, aliphatic 
acids and benzamides (7). HDACIs have received considerable attention for treating cancers by reason of improved patient compliance and minimum side effects (10). Among these compounds, suberoylanilide hydroxamic acid (SAHA) and Romidepsin have already been approved by the Food and Drug Administration (FDA), USA for treatment of cutaneous T-cell lymphoma $(11,12)$.

Previous studies revealed that trichostatin A (TSA), a hydroxamic acid-based inhibitor, could induce cell growth arrest, differentiation and/or apoptosis in a number of cancer cells $(13,14)$. However, therapeutic application of TSA is limited due to poor bioavailability in vivo and toxicity at high doses (15). SAHA is a subsequent hydroxamic acid-based HDACI and the leading compound in a new promising class of anticancer drugs. It is relatively safe and non-toxic in vivo and has improved properties over TSA $(15,16)$. Moreover, SAHA has significant antitumor effects against a wide variety of tumor types at dosages that can be tolerated by patients when administered intravenously and orally (10). Considering the aforementioned scenario, we selected TSA and SAHA to study the anticancer potential in combinatorial approach.

HDACIs with unique and complementary mode of action have been reported to show additive or synergistic anticancer activities with some platinum-based chemotherapeutic agents, including cisplatin in various cancer cell lines in vitro and in vivo (17). Though a wide-ranging knowledge of mechanism of tumor sensitivity to cisplatin and HDACIs has been achieved, several basic aspects in combination therapy for CCA are yet to be understood. Therefore, investigating these aspects in the context of combinative therapy in vitro and exploitation of this knowledge will further improve the design of optimized clinical protocols.

\section{Materials and methods}

Reagents. Cisplatin, SAHA and TSA were purchased from Sigma-Aldrich (St. Louis, MO, USA). Culture media and its supplements including antibiotics and fetal bovine serum (FBS) were purchased from Gibco, Invitrogen Corp. (Carlsbad, CA, USA). FITC Annexin V apoptosis detection kit was purchased from BioLegend Inc. (San Diego, CA, USA). Antibodies against p53, p21 and CDK4 and Bcl-2 were purchased from Cell Signaling Technology, Inc. (Beverly, MA, USA). Cisplatin was dissolved in normal saline. SAHA and TSA were dissolved in DMSO. The final concentration of DMSO was $<0.5 \%$.

Cell lines and cell culture. Two CCA cell lines (poorly differentiated KKU-100 and well-differentiated KKU-M214 adenocarcinoma cells established from opisthorchiasis-associated Thai CCA patients) and a non-cancer cell line (H69; human bile duct epithelial cells kindly donated by Dr D. Jefferson, Tufts University, Boston, MA, USA) were used in this study. Cancer cells were maintained in RPMI-1640 medium supplemented with $10 \%$ FBS, penicillin $(100 \mathrm{U} / \mathrm{ml})$ and streptomycin $(100 \mu \mathrm{g} / \mathrm{ml})($ Gibco-BRL). H69 cells were grown in Dulbecco's minimum essential medium (DMEM; Gibco, Invitrogen Corp.) supplemented with $10 \%$ FBS, penicillin $(100 \mathrm{U} / \mathrm{ml})$, streptomycin $(100 \mu \mathrm{g} / \mathrm{ml})$, adenine $(25 \mu \mathrm{g} / \mathrm{ml})$, epinephrine $(1 \mu \mathrm{g} / \mathrm{ml})$, insulin $(5 \mu \mathrm{g} / \mathrm{ml}), \mathrm{T}_{3} \mathrm{~T}$ Triiodo-L-thyronine $(13.6 \mathrm{ng} / \mathrm{ml})$, holo-transferrin $(8.3 \mu \mathrm{g} / \mathrm{ml})$, hydrocortisone $(0.62 \mu \mathrm{g} / \mathrm{ml})$ and EGF $(10 \mathrm{ng} / \mathrm{ml})$. The cells were incubated at $37^{\circ} \mathrm{C}$ in a humidified atmosphere containing $5 \% \mathrm{CO}_{2}$.

Antiproliferative activity assay. Antiproliferative effect on cells was determined by 3-(4,5-dimethylthiazol-2-yl)-2,5-diphenyltetrazolium bromide (MTT) assay as previously described (18). Briefly, cells $\left(8 \times 10^{3}\right.$ cells/well) were cultured in 96-well plates. After $24 \mathrm{~h}$, cells were treated with different concentrations of cisplatin and HDACIs (SAHA and TSA) for 24,48 and $72 \mathrm{~h}$. For combination study, cells were treated with single subtoxic concentration [the concentration causing $20 \%$ growth inhibition $\left(\mathrm{IC}_{20}\right)$ ] of cisplatin and HDACIs (SAHA and TSA) alone and in combination. After indicated periods, medium was replaced with fresh medium containing MTT. After a $2 \mathrm{~h}$-incubation, the formazan from MTT reduction was dissolved in DMSO, and the absorbance at $550 \mathrm{~nm}$ was measured with a microtiter plate reader (Bio-Rad Laboratories, Hercules, CA, USA) using $655 \mathrm{~nm}$ as a reference wavelength. Cell viability was determined as percentage by following equation: \% Cell viability $=[$ Sample OD/Control OD $] \times 100$.

Determination of drug interaction. The interactions between cisplatin and HDACIs (SAHA and TSA) were evaluated by calculating combination index (CI) according to median-effect principle $(19,20)$. For $50 \%$ growth inhibition, the CI values for agents with mutually non-exclusive mode of action were calculated based on the following equation

$$
C l=\frac{(D) 1}{(D x) 1}+\frac{(D) 2}{(D x) 2}+\alpha \frac{(D) 1 \cdot(D) 2}{(D x) 1 \cdot(D x) 2}
$$

where (Dx)1, dose of drug 1 (cisplatin) to produce 50\% growth inhibition alone; (D)1, dose of drug 1 to produce $50 \%$ growth inhibition in combination with (D)2; (Dx)2, dose of drug 2 (HDACIs) to produce $50 \%$ growth inhibition alone; (D)2, dose of drug 2 to produce $50 \%$ growth inhibition in combination with (D) $1 ; \alpha=1$ for mutually non-exclusive modes of drug actions. $\mathrm{CI}<1$ indicates synergism; $\mathrm{CI}=1$ indicates an additive relationship; and $\mathrm{CI}>1$ indicates antagonism. The dose reduction index (DRI) indicates the extent of dose reduction in a favorable combination for a given level of effect as compared to the dose of a single agent. The equation for dose reduction is as follows $(19,20)$ :

$$
(\mathrm{DRI}) 1=\frac{(\mathrm{Dx}) 1}{(\mathrm{D}) 1} \quad(\mathrm{DRI}) 2=\frac{(\mathrm{Dx}) 2}{(\mathrm{D}) 2}
$$

Cell cycle analysis by flow cytometry. Briefly, cells $\left(2.5 \times 10^{5}\right.$ cells $\left./ \mathrm{ml}\right)$ were seeded in culture dish and treated with cisplatin and HDACIs (SAHA and TSA) alone and in combination for $24 \mathrm{~h}$. Following $24 \mathrm{~h}$ incubation, cells were harvested and fixed in $70 \%$ cold ethanol at $4^{\circ} \mathrm{C}$ for $1 \mathrm{~h}$. After fixation, cells were washed with PBS and incubated with $0.5 \mathrm{mg} / \mathrm{ml}$ RNase A (Sigma) at $37^{\circ} \mathrm{C}$ for $1 \mathrm{~h}$. Nuclear DNA was stained using propidium iodide (PI) $(50 \mu \mathrm{g} / \mathrm{ml})$ under subdued light for $30 \mathrm{~min}$ at room temperature. The DNA histograms, reflecting cell cycle distribution, were assessed by using BD FACSanto II Calibur Flow Cytometer (Becton-Dickinson, San Jose, CA, USA).

Apoptosis assay. The induction of apoptosis was analyzed using a FITC-Annexin V apoptosis detection kit according to 
Table I. Combination index (CI) and dose reduction index (DRI) at $\mathrm{IC}_{50}$ values of cisplatin and HDACIs (SAHA and TSA) against CCA cells for $72 \mathrm{~h}$.

\begin{tabular}{llcccr}
\hline & & & \multicolumn{2}{c}{ DRI } \\
\cline { 5 - 6 } Cell type & Drug combination & CI & Cisplatin & SAHA & TSA \\
\hline KKU-100 & Cisplatin + SAHA & 0.766 & 2.95 & 3.1 & 3.03 \\
& Cisplatin + TSA & 0.887 & 2.59 & & 3.08 \\
KKU-M214 & Cisplatin + SAHA & 0.884 & 2.36 & 3.23 \\
& Cisplatin + TSA & 0.838 & 2.48 & & 3.08 \\
\hline
\end{tabular}

CCA, cholangiocarcinoma; HDACIs histone deacetylase inhibitors; SAHA, suberoylanilide hydroxamic acid; TSA, trichostatin A.

the manufacturer's instructions. Briefly, cells $\left(2.5 \times 10^{5}\right.$ cells $\left./ \mathrm{ml}\right)$ were seeded in culture dish and treated with cisplatin and HDACIs (TSA and SAHA) alone and in combination for 24 h. Cells were harvested, washed with cold PBS and resuspended in the Annexin V-binding buffer. Then cells were incubated with Annexin V-FITC and PI at room temperature for $15 \mathrm{~min}$, and then analyzed by flow cytometry by using a BD FACSanto II Calibur Flow Cytometer (Becton-Dickinson). The flow cytometry results were compared with conventional cell count and morphology under a fluorescence microscope.

Western blot analysis of cell cycle and apoptosis regulating proteins. After treatment with HDACIs and cisplatin alone or in combination, total cellular protein were extracted using cell sample lysis buffer (50 mM Tris- $\mathrm{HCl}, 150 \mathrm{mM} \mathrm{NaCl}, 1 \mathrm{mM}$ EDTA, $1 \%$ Triton X-100, 0.1\% SDS, $0.1 \%$ sodium deoxycholate) containing protease inhibitor cocktail (Roche Diagnostics) and $1 \mathrm{mM}$ phenylmethylsulfonyl fluoride (Wako Pure Chemical Industries, Osaka, Japan). Equal amounts of total protein were resolved by SDS-PAGE (12-12.5\%). After electrophoresis, the proteins were transferred to PVDF membrane and blocked with 5\% skim milk for $1 \mathrm{~h}$. The membrane was incubated with a primary antibody $(1: 1,000)$ against p53, p21 and CDK4 and Bcl- 2 at $4^{\circ} \mathrm{C}$ overnight. Following incubation, membrane was washed with PBST twice each and incubated with horseradish peroxidase-conjugated secondary antibody (GE Healthcare, Little Chalfont, UK) for $2 \mathrm{~h}$ at RT. After washing, immunoreactive bands were visualized by chemiluminescence (Upstate, Charlottesville, VA, USA). The antibody against $\beta$-actin was used as loading control in western blot analysis. The intensity of protein bands was quantitated by densitometric analysis using ImageJ (1.47v) program.

Statistical analysis. All experiments were conducted three times. Data were expressed as means \pm standard deviation (SD) from three independent experiments. Duncan's post hoc was performed using statistical program of IBM SPSS Statistic version 20.0 for Mac (SPSS Corp., Chicago, IL, USA) for testing significant differences between solvent controls and sample-treated cells. The criterion for statistical significance was set at $\mathrm{p}<0.05$.

\section{Results}

Antiproliferative activity of cisplatin and HDACIs (SAHA and TSA) against CCA cells. The in vitro antiproliferative activity of cisplatin, SAHA and TSA in both KKU-100 and KKU-M214 cells were examined. Exposure to each drug resulted in significant growth inhibition and cytotoxicity in both cell lines in a concentration- and time-dependent manner (Fig. 1). Cellular sensitivities for each drug were determined by their $\mathrm{IC}_{50}$ values. The results presented in Fig. 1 show that cisplatin significantly inhibited proliferation of KKU-100 and KKU-M214 cells, with $\mathrm{IC}_{50}$ values of $7.57 \pm 0.35$ and $12.98 \pm 0.61 \mu \mathrm{M}$, respectively. The viability of KKU-100 and KKU-M214 cells significantly decreased after SAHA treatments for $72 \mathrm{~h}$, with $\mathrm{IC}_{50}$ values of $1.41 \pm 0.01$ and $1.85 \pm 0.06 \mu \mathrm{M}$ in KKU-100 and KKU-M214 cells, respectively. Likewise, TSA exhibited antiproliferative activity against both KKU-100 and KKU-M214 cells with $\mathrm{IC}_{50}$ values of $435.64 \pm 35.15$ and $516.08 \pm 8.04 \mathrm{nM}$, respectively.

Antiproliferative activity against CCA cells of cisplatin and HDACIs (SAHA and TSA) in combinations. The combined effects of cisplatin and HDACIs (SAHA and TSA) on proliferation of CCA cells are illustrated in Fig. 1G and H. KKU-100 cells were treated with cisplatin $(3 \mu \mathrm{M})$, SAHA $(0.5 \mu \mathrm{M})$, TSA $(200 \mathrm{nM})$, cisplatin $(3 \mu \mathrm{M})+$ SAHA $(0.5 \mu \mathrm{M})$ and cisplatin $(3 \mu \mathrm{M})+$ TSA $(200 \mathrm{nM})$; KKU-M214 cells were treated with cisplatin $(6 \mu \mathrm{M})$, SAHA $(0.75 \mu \mathrm{M})$, TSA $(250 \mathrm{nM})$, cisplatin $(6 \mu \mathrm{M})+\operatorname{SAHA}(0.75 \mu \mathrm{M})$ and cisplatin $(6 \mu \mathrm{M})+\mathrm{TSA}(250 \mathrm{nM})$ for $72 \mathrm{~h}$ and then analyzed by MTT assay. The combination of cisplatin and HDAC inhibitors significantly reduced cell viability more than either agent alone. In KKU-100 cells, exposure to combinations of cisplatin + SAHA and cisplatin + TSA reduced cell viability to $41.76 \pm 3.23$ and $39.43 \pm 3.46 \%$, respectively, whereas cisplatin, SAHA and TSA alone decreased the cell viability to $74.50 \pm 2.21,80.34 \pm 1.34$ and $77.23 \pm 4.40 \%$, respectively. Similar trends were also observed in KKU-M214 cells where cell viability was significantly reduced more for combined treatments of cisplatin and HDACIs $(42.63 \pm 1.98 \%$ for cisplatin + SAHA and $40.02 \pm 1.23 \%$ for cisplatin + TSA) than single agent treatment $(72.65 \pm 1.87 \%$ for cisplatin, $76.63 \pm 3.67 \%$ for SAHA and $75.70 \pm 1.97 \%$ for TSA).

CI and DRI. As cytotoxicity is probably the most important parameter for a successful cancer treatment modality, it is, thus, important to evaluate whether or not the combination of these two types of agents has additive or synergistic cytotoxic effects in CCA cell lines. As presented in Table I, the results revealed that the simultaneous combination of cisplatin and HDACIs (SAHA and TSA) produced synergistic cytotoxic 

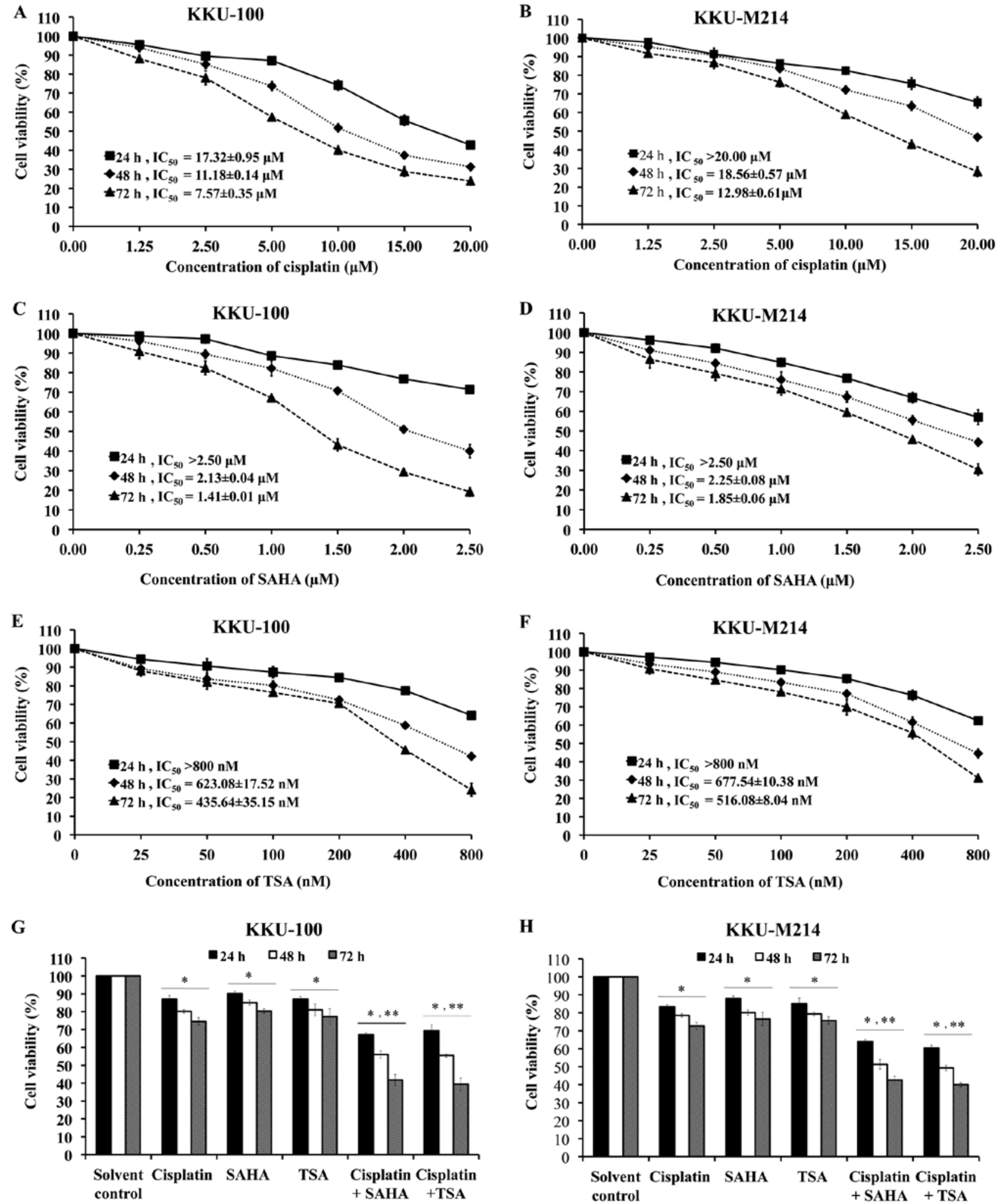

Figure 1. Antiproliferative activity of cisplatin, SAHA and TSA alone or in combination against KKU-100 and KKU-M214 cells. KKU-100 cells (A, C and E) and KKU-M214 cells (B D and F) were cultured, treated with various concentrations of cisplatin, SAHA and TSA for 24,48 and $72 \mathrm{~h}$, and then analyzed by MTT assay. For combination study, KKU-100 cells (G) were treated with cisplatin $(3 \mu \mathrm{M})$, SAHA $(0.5 \mu \mathrm{M})$, TSA $(200 \mathrm{nM})$, cisplatin $(3 \mu \mathrm{M})+\mathrm{SAHA}(0.5 \mu \mathrm{M})$ and cisplatin $(3 \mu \mathrm{M})+$ TSA $(200 \mathrm{nM})$; KKU-M214 cells $(\mathrm{H})$ were treated with cisplatin $(6 \mu \mathrm{M})$, SAHA $(0.75 \mu \mathrm{M})$, TSA $(250 \mathrm{nM})$, cisplatin $(6 \mu \mathrm{M})+$ SAHA $(0.75 \mu \mathrm{M})$ and cisplatin $(6 \mu \mathrm{M})+\mathrm{TSA}(250 \mathrm{nM})$. Data of cell viability percentage are expressed as means \pm SD of three independent experiments. ${ }^{*} \mathrm{p}<0.05$ significant difference between treatments and solvent control; ${ }^{* *} \mathrm{p}<0.05$ significant difference between the combination treatment and single treatment.

effect as evidenced by the CI values of $<1$, which result in favorable dose reduction of both cisplatin and HDACIs (SAHA and TSA).
Antiproliferative activity of $H 69$ cells for cisplatin and HDACIs (SAHA and TSA) alone or in combination. To further justify the therapeutic application of drug combination, the impact 
Table II. Effect of cisplatin and HDACIs (SAHA and TSA) alone and in combination on cell cycle distribution of CCA cells.

\begin{tabular}{|c|c|c|c|c|c|}
\hline \multirow[b]{2}{*}{ Cell lines } & \multirow[b]{2}{*}{ Treatments } & \multicolumn{4}{|c|}{ Cell cycle distribution (means \pm SD) $\%$} \\
\hline & & Sub-G1 & G0/G1 & $\mathrm{S}$ & $\mathrm{G} 2 / \mathrm{M}$ \\
\hline \multirow[t]{8}{*}{ KKU-100 } & Solvent control & $3.26 \pm 0.49$ & $35.60 \pm 2.10$ & $27.83 \pm 0.75$ & $33.31 \pm 1.51$ \\
\hline & $10 \mu \mathrm{M}$ cisplatin & $13.88 \pm 1.56^{\mathrm{a}}$ & $56.10 \pm 1.44^{\mathrm{a}}$ & $13.15 \pm 3.25^{\mathrm{a}}$ & $16.87 \pm 1.27^{\mathrm{a}}$ \\
\hline & $1.5 \mu \mathrm{M}$ SAHA & $9.25 \pm 0.62^{\mathrm{a}}$ & $60.70 \pm 1.49^{a}$ & $9.80 \pm 1.14^{\mathrm{a}}$ & $20.25 \pm 1.51^{\mathrm{a}}$ \\
\hline & 400 nM TSA & $7.12 \pm 0.37$ & $65.93 \pm 1.94^{\mathrm{a}}$ & $6.75 \pm 1.41^{\mathrm{a}}$ & $20.20 \pm 1.41^{\mathrm{a}}$ \\
\hline & $10 \mu \mathrm{M}$ cisplatin & & & & \\
\hline & $+1.5 \mu \mathrm{M} \mathrm{SAHA}$ & $26.40 \pm 1.56^{\mathrm{a}, \mathrm{b}}$ & $45.50 \pm 1.41^{\mathrm{a}, \mathrm{b}}$ & $15.70 \pm 1.97^{\mathrm{a}}$ & $12.40 \pm 1.70^{\mathrm{a}}$ \\
\hline & $10 \mu \mathrm{M}$ cisplatin & & & & \\
\hline & +400 nM TSA & $20.45 \pm 1.21^{\mathrm{a}, \mathrm{b}}$ & $49.50 \pm 1.42^{\mathrm{a}, \mathrm{b}}$ & $16.90 \pm 1.13^{\mathrm{a}, \mathrm{b}}$ & $13.15 \pm 1.50^{\mathrm{a}}$ \\
\hline \multirow[t]{8}{*}{ KKU-M214 } & Solvent control & $4.02 \pm 1.38$ & $66.70 \pm 1.63$ & $13.10 \pm 1.75$ & $16.18 \pm 1.28$ \\
\hline & $10 \mu \mathrm{M}$ cisplatin & $18.85 \pm 1.38^{\mathrm{a}}$ & $46.10 \pm 1.48^{\mathrm{a}}$ & $16.35 \pm 2.05$ & $18.70 \pm 1.15$ \\
\hline & $1.5 \mu \mathrm{M}$ SAHA & $19.85 \pm 3.04^{\mathrm{a}}$ & $52.55 \pm 2.31^{\mathrm{a}}$ & $12.35 \pm 2.19$ & $15.25 \pm 1.91$ \\
\hline & 400 nM TSA & $17.56 \pm 2.06^{\mathrm{a}}$ & $50.95 \pm 3.46^{\mathrm{a}}$ & $16.69 \pm 1.13$ & $14.8 \pm 0.71$ \\
\hline & $10 \mu \mathrm{M}$ cisplatin & & & & \\
\hline & $+1.5 \mu \mathrm{M}$ SAHA & $36.90 \pm 1.56^{\mathrm{a}, \mathrm{b}}$ & $49.20 \pm 1.70^{\mathrm{a}}$ & $9.50 \pm 0.71$ & $4.40 \pm 0.57^{\mathrm{a}, \mathrm{b}}$ \\
\hline & $10 \mu \mathrm{M}$ cisplatin & & & & \\
\hline & +400 nM TSA & $35.59 \pm 1.63^{\mathrm{a}, \mathrm{b}}$ & $45.70 \pm 1.13^{\mathrm{a}}$ & $15.40 \pm 0.71$ & $3.31 \pm 0.78^{\mathrm{a}, \mathrm{b}}$ \\
\hline
\end{tabular}

${ }^{\mathrm{a}} \mathrm{p}<0.05$, significant difference compared with solvent control; ${ }^{\mathrm{b}} \mathrm{p}<0.05$, significant difference compared with single treatment.

of this combination on non-cancer H69 cell proliferation was examined. For combination, the highest sub-toxic doses of each agent used against KKU-100 and KKU-M214 cells were selected to evaluate. Dose-response curve demonstrates that cisplatin, SAHA and TSA were relatively ineffective against H69 cells (Fig. 2). Cisplatin $(6.0 \mu \mathrm{M})$ alone decreased cell viability to $81.06 \pm 3.85 \%$ for $72 \mathrm{~h}$. When it was used in combination with SAHA $(0.75 \mu \mathrm{M})$ and TSA $(250 \mathrm{nM})$, the viability was reduced to $64.29 \pm 1.3$ and $59.15 \pm 2.36 \%$, respectively. These values of cell viability, however, are still higher than that of KKU-100 and KKU-M214 cells after concurrent cisplatin and SAHA or TSA treatment (Fig. 2). This, therefore, indicates that combination of cisplatin and HDACIs preferentially inhibited the proliferation of cancer cells to non-cancer cells.

Effect on cell cycle progression by cisplatin and HDACIs (SAHA and TSA) alone and in combination. To elucidate if the cytotoxic potentiation of cisplatin-induced cytotoxicity by HDACIs is associated with alteration of cell cycle progression, we examined the cell cycle profiles of PI-stained cells using flow cytometry. This type of analysis is based on nuclear DNA content and quantitates the distribution of cells in the G0/G1 ( 2 n DNA content), $S$ (2n-4n DNA content) and G2/M (4n DNA content) phases of the cell cycle. As presented in Table II, in KKU-100 cells, exposure to cisplatin $(10 \mu \mathrm{M})$ retarded cell cycle at $\mathrm{G} 0 / \mathrm{G} 1$ phase with $56.10 \pm 1.44 \%$ of cells. Likewise SAHA $(1.5 \mu \mathrm{M})$ and TSA $(400 \mathrm{nM})$ induced evidence of a cell cycle arrest, with accumulation of cells $(60.7 \pm 1.49$ and $65.93 \pm 1.94 \%$, respectively) in G0/G1 along. When cisplatin and HDAC inhibitors were used in combination, there was a greater sub-G1 population $(26.4 \pm 1.56 \%$ for cisplatin + SAHA,
$20.45 \pm 1.21 \%$ for cisplatin + TSA) than either drug alone $(13.88 \pm 1.56 \%$ for cisplatin, $9.25 \pm 0.62 \%$ for SAHA, and $7.12 \pm 0.37 \%$ for TSA). In addition, more percentage of cells at G0/G1 phase was found with cisplatin + SAHA $(45.5 \pm 1.41 \%)$ or cisplatin + TSA $(49.5 \pm 1.42 \%)$ combination when compared with the control $(35.60 \pm 2.10 \%)$.

Unlike KKU-100 cells, treatment with cisplatin $(10 \mu \mathrm{M})$ and HDACIs (1.5 $\mu \mathrm{M}$ SAHA and $400 \mathrm{nM}$ TSA) alone or in combination produced no evidence of cell cycle arrest in any particular phase of the cell cycle in KKU-M214 cells, but increased sub-G1 population (Fig. 3). Combination treatments caused more sub-G1 percent $(36.9 \pm 1.56 \%$ for cisplatin + SAHA, $35.59 \pm 1.63 \%$ for cisplatin + TSA) in comparison to control and single agents. The sub-G1 population of combination treatments was significantly different from control and single agent treatment. DNA histogram representing proportions of cells in different phases of cell cycle are shown in Fig. 3. These findings suggest that the cytotoxic potentiation associated with combination is independent of cell cycle arrest in KKU-M214 cells.

Apoptosis induction by cisplatin and HDACIs (SAHA and TSA) alone and in combination. After evaluation of cell cycle profiles, we further aimed to evaluate the induction of apoptosis in KKU-100 and KKU-M214 cells. As depicted in Fig. 4, each drug combination showed significantly higher apoptotic percentage as compared to single agent treatment. The simultaneous combination of cisplatin $(10 \mu \mathrm{M})$ plus SAHA $(1.5 \mu \mathrm{M})$ produced $30.15 \pm 1.29$ and $27.10 \pm 1.22 \%$ of early apoptosis in KKU-100 and KKU-M214 cells, respectively, as evidenced by Annexin V/FITC-positive and PI-negative population. By contrast, cisplatin $(10 \mu \mathrm{M})$ and SAHA $(1.5 \mu \mathrm{M})$ alone 
A

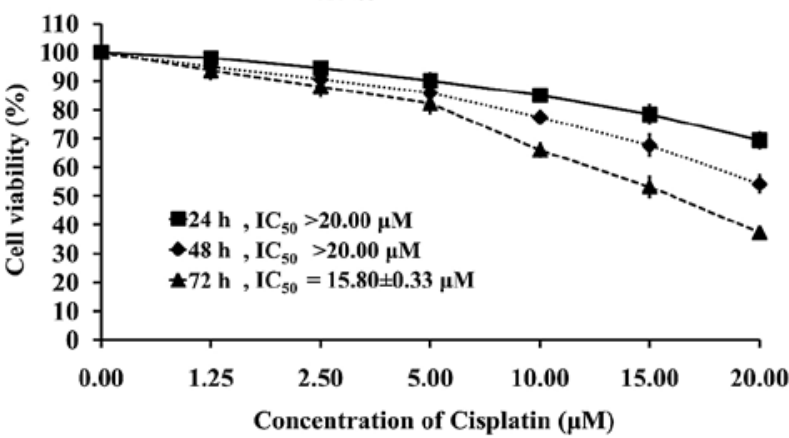

C

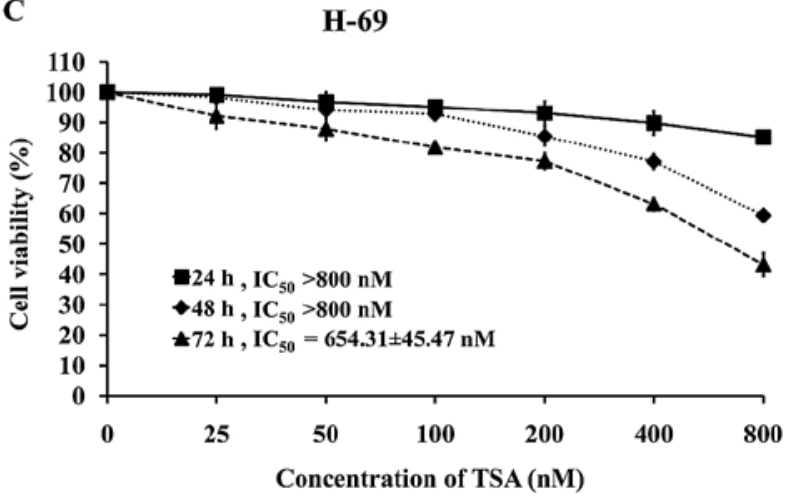

B

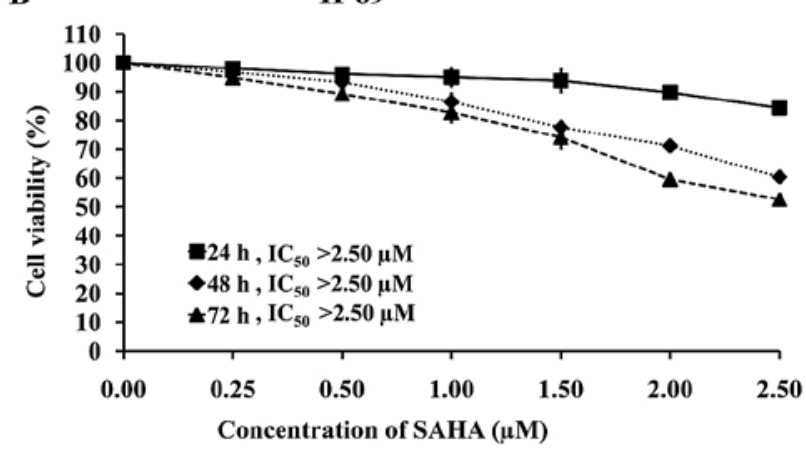

D

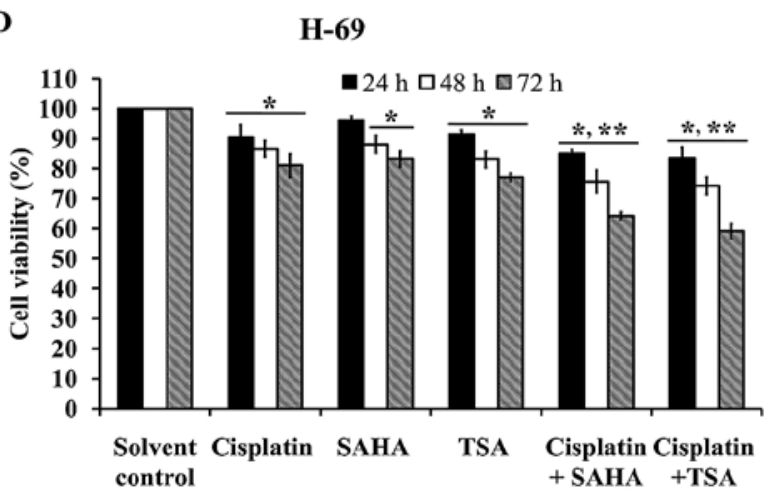

Figure 2. Antiproliferative activity of cisplatin, SAHA and TSA alone or in combination against H-69 cells. H-69 cells (A-C) were cultured, treated with cisplatin, SAHA and TSA for 24, 48 and $72 \mathrm{~h}$, and then analyzed by MTT assay. For combination study, H-69 cells (D) were treated with cisplatin (6 $\mu$ M), SAHA $(0.75 \mu \mathrm{M})$, TSA $(250 \mathrm{nM})$, cisplatin $(6 \mu \mathrm{M})+$ SAHA $(0.75 \mu \mathrm{M})$ and cisplatin $(6 \mu \mathrm{M})+$ TSA $(250 \mathrm{nM})$. Data of cell viability percentage are expressed as means \pm SD of three independent experiments. ${ }^{*} \mathrm{p}<0.05$ significant difference between treatments and solvent control; ${ }^{* *} \mathrm{p}<0.05$ significant difference between the combination treatment and single treatment.

induced only $13.77 \pm 2.02$ and $13.87 \pm 0.90 \%$ in KKU-100, and $13.28 \pm 1.56$ and $13.37 \pm 1.51 \%$ in KKU-M214 cells, respectively. Another combination comprising of cisplatin $(10 \mu \mathrm{M})$ and TSA (400 nM) demonstrated similar trends of apoptosis in both cell lines. Exposure to TSA induced the apoptotic cell death of $13.14 \pm 0.94$ and $12.75 \pm 1.48 \%$ in KKU-100 and KKU-M214 cells, respectively, while cisplatin and TSA combination increased apoptosis to $28.72 \pm 2.21$ and $26.02 \pm 1.17 \%$, respectively.

Detection of p53, p21, CDK4 and Bcl-2 proteins on western blotting. Since data from flow cytometry analysis provided evidence of apoptosis induction and cell cycle profile perturbation with cisplatin and HDACIs alone and in combination, we conducted western blotting to assess protein factors involved with cell cycle arrest and pro-apoptotic responses. The expression of gene products in response to drugs treatment for $24 \mathrm{~h}$ was studied in KKU-100 and KKU-M214 cells. As depicted in Fig. 5, treatment with cisplatin, SAHA and TSA alone or in combination upregulated p53 and p21 in KKU-100 in comparison to control while expression of CDK4 and Bcl-2 was downregulated. The expression status of p53 was profound in co-treatment of cisplatin and SAHA or TSA compared to single-agent treatment while p21 was not as expected. In KKU-M214 cells, p53, CDK4 and Bcl-2 expression was not affected with single or combination treatment though apoptosis was induced with the tested dose. However, combination of cisplatin and HDACIs increased the expression of p21 moderately to slightly. As both the cell lines are of wild type p53 status, our western blot results suggest that apoptosis upon combination treatment may be via p53 dependent pathway in KKU-100 cells while in KKU-M214 may be p53-independent.

\section{Discussion}

Combination chemotherapy is the first choice modality for treating many types of cancer. Combining drugs that target different oncogenic cell signaling pathways often erase adverse side-effects and complication in patients while increasing the efficacy of treatment and reducing morbidity (5). Many studies on cancer cell lines pointed out dose-dependent antiproliferative activity of HDACIs. It was reported that SAHA and TSA inhibited the proliferation of TAMR/MCF-7 cells, NSCLC cells and retinoblastoma cells in a dose-dependent manner (21-23). In agreement with the earlier findings, the inhibition of cell proliferation in CCA cells was dose and time-dependent for all cases.

In addition, our data demonstrated that administration of a low dose of cisplatin and HDACIs alone had little effect on CCA cells. On the contrary, the combined use of cisplatin and HDACIs resulted in a greater inhibition of cell growth for both KKU-100 and KKU-M214 cells than either agent alone. Previous findings agree with our results regarding antiproliferative activity of combined HDACIs and cisplatin against various cell lines. SAHA and cisplatin combination resulted in more profound cytotoxicity than individual cisplatin or SAHA in oral squamous cell carcinoma (24-26), in human glioblastoma D54 and breast cancer MCF-7 cells (27), and platinum resistant 
A
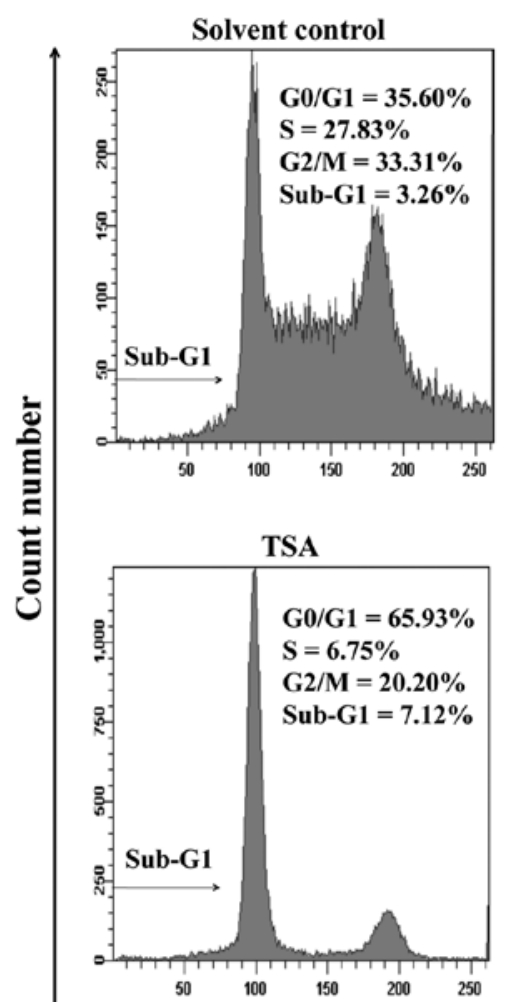

KKU-100
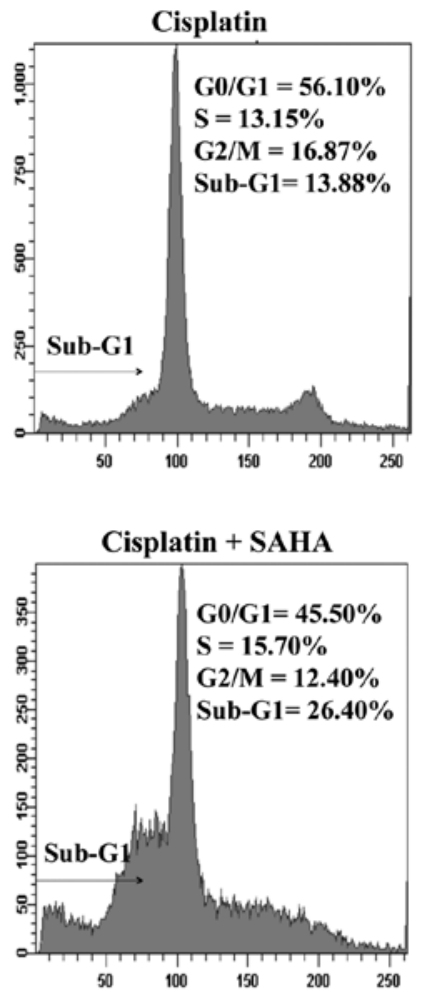

Propidium iodide (PI)
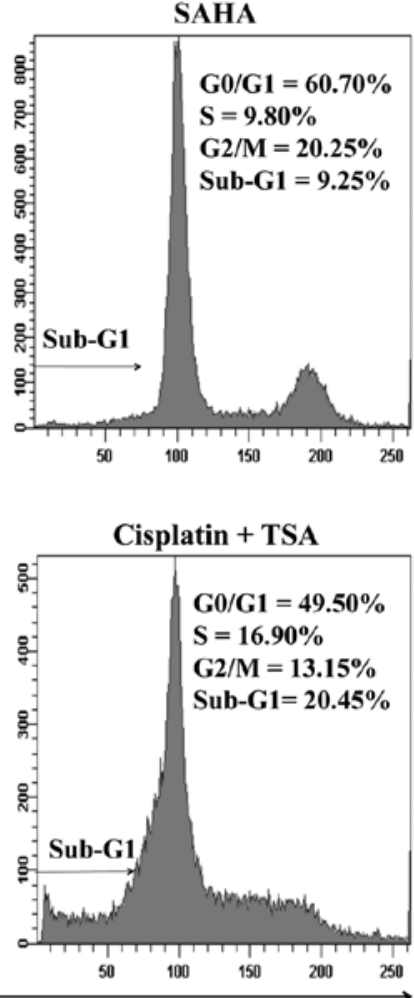

B

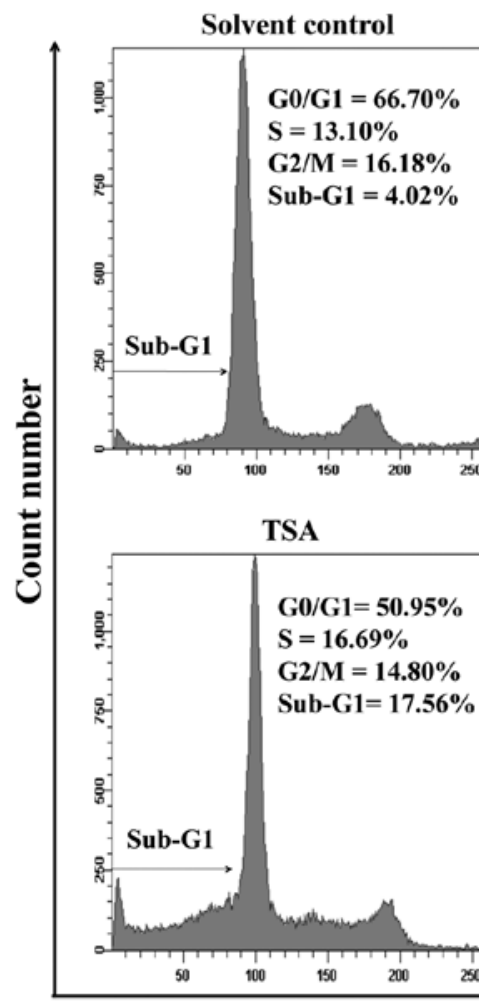

KKU-M214
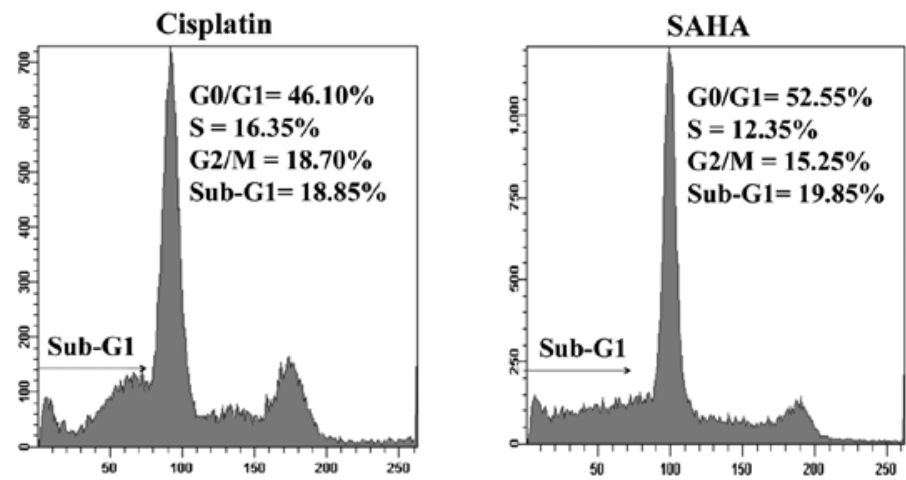

Cisplatin + SAHA
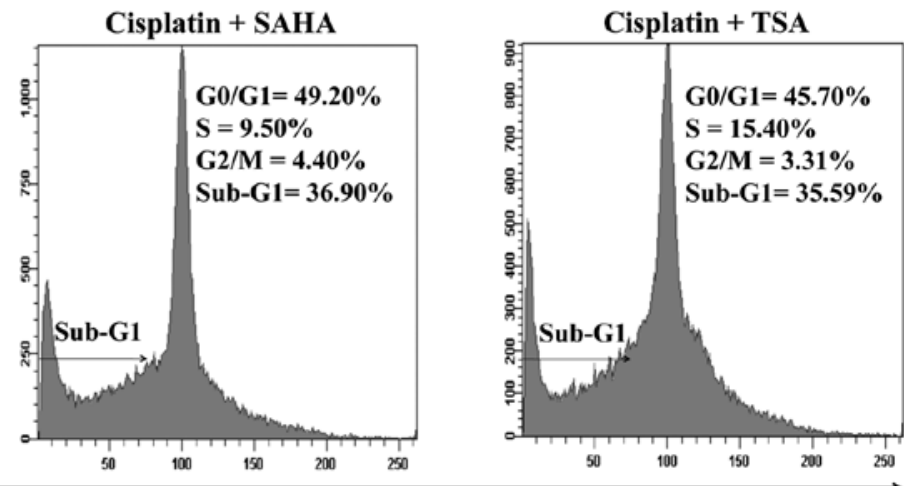

Propidium iodide (PI)

Figure 3. DNA histograms representing cell cycle profiles of KKU-100 (A) and KKU-M214 (B) cells. Cells treated with DMSO (0.5\%) as control, cisplatin $(10 \mu \mathrm{M})$, SAHA $(1.5 \mu \mathrm{M})$ and TSA $(400 \mathrm{nM})$ alone or in combination for $24 \mathrm{~h}$ were subjected to cell cycle analysis by flow cytometry using propidium iodide (PI) staining. Data shown are the means \pm SD of three independent experiments. Histograms showed a number of cells per channel (vertical axis) vs. DNA content (horizontal axis). Percentage of cells at various phases of cell cycle after the treatment with drugs varied. 
A

KKU-100

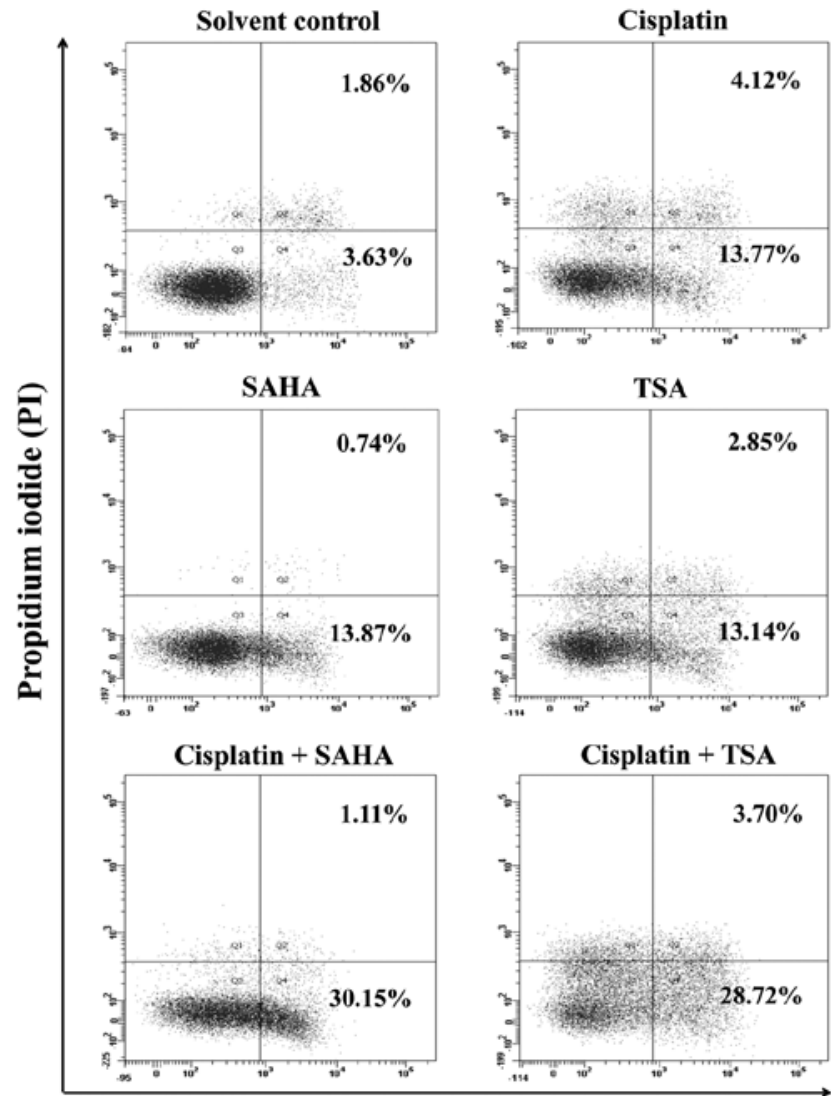

Annexin V-FITC

C

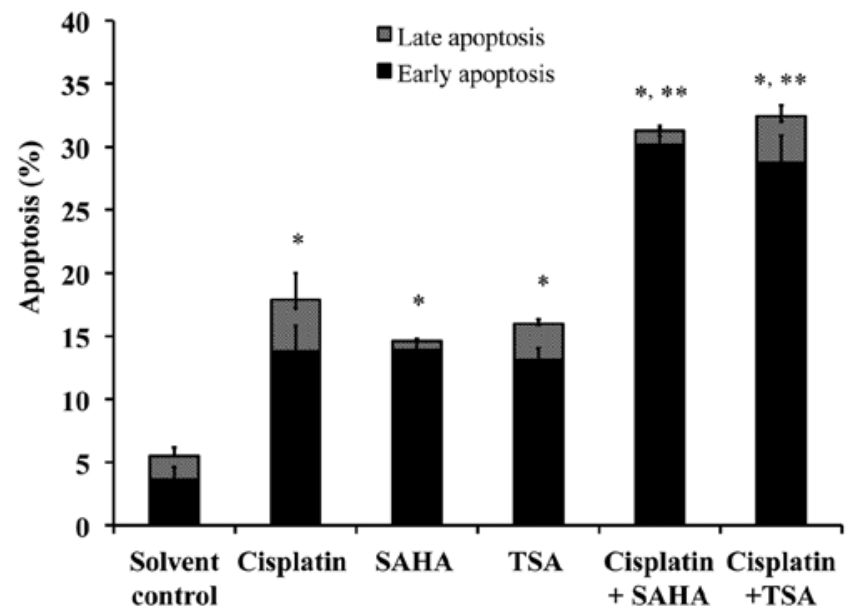

B

KKU-M214

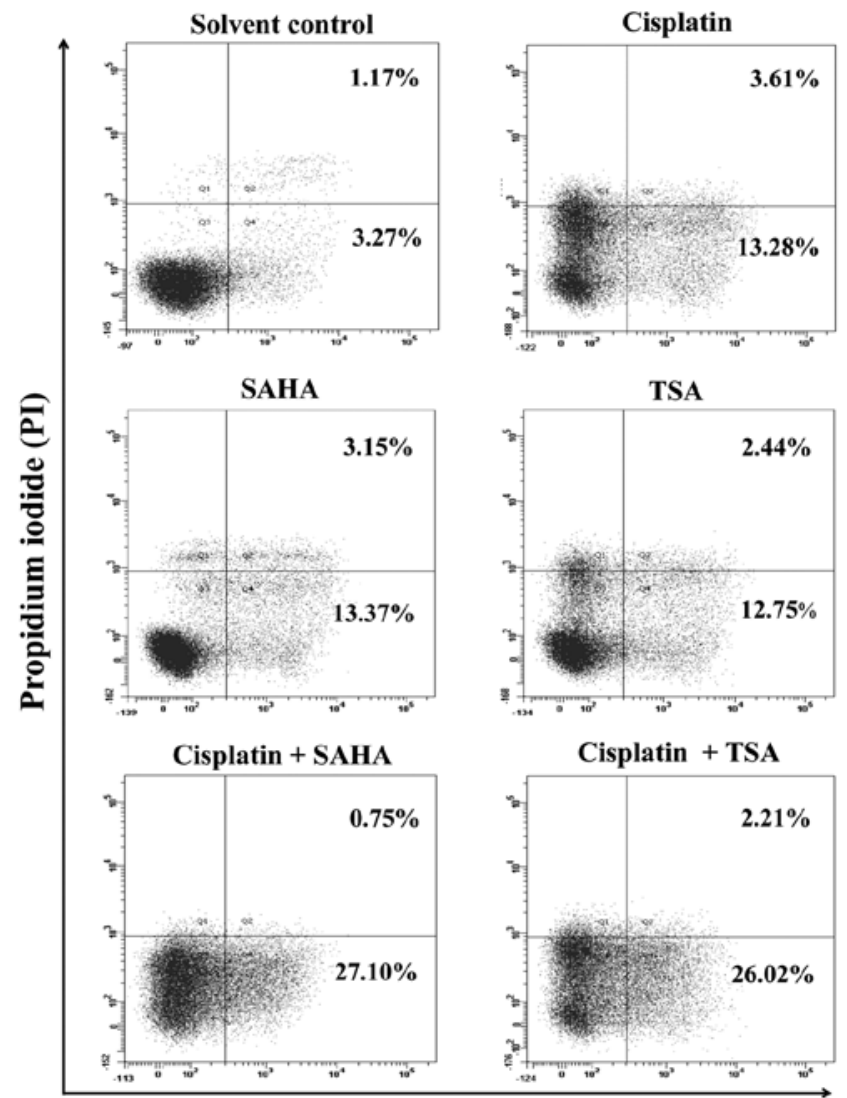

Annexin V-FITC

D

KKU-M214

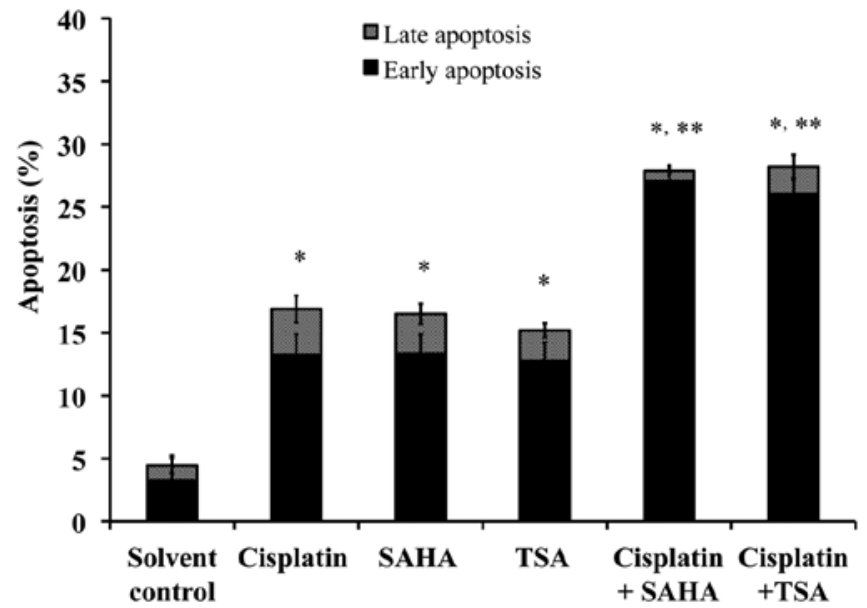

Figure 4. Apoptosis induction by cisplatin, SAHA and TSA alone or in combination in KKU-100 and KKU-M214 cells. (A and B) Representative dot plots from flow cytometry for apoptosis induction in KKU-100 and KKU-M214 cells, respectively; (C and D) Apoptosis for KKU-100 and KKU-M214 cells, respectively. Cells were treated with DMSO $(0.5 \%)$ as a control, cisplatin $(10 \mu \mathrm{M})$, SAHA $(1.5 \mu \mathrm{M})$ and TSA $(400 \mathrm{nM})$ alone or in combination for $24 \mathrm{~h}$. After $24 \mathrm{~h}$, cells were analyzed for apoptosis induction using Annexin V-FITC/propidium iodide (PI) staining with flow cytometry. Data shown are the means \pm SD of three independent experiments. " $\mathrm{p}<0.05$ significant difference between treatments and solvent control; ${ }^{* *} \mathrm{p}<0.05$ significant difference between the combination treatment and single treatment.

OVCAR-3 and SKOV-3 cells (28). Several studies indicated favorable drug interactions between TSA and cisplatin in various platinum-resistant and non-resistant cancer cell lines. It was reported that TSA increases cytotoxicity of cisplatin in human glioblastoma (D54) and breast cancer (MCF-7) (27). Furthermore, TSA is reported to enhance the cytotoxic effects of human ovarian and colon cancer cell lines with crossresistance to a wide range of DNA-damaging drugs and reduce the dose of chemotherapeutics (29).

In this study, the simultaneous co-treatment with cisplatin and HDACIs conferred a significant synergistic cytotoxic effect on the CCA cell lines rather than a simple additive effect. 
A

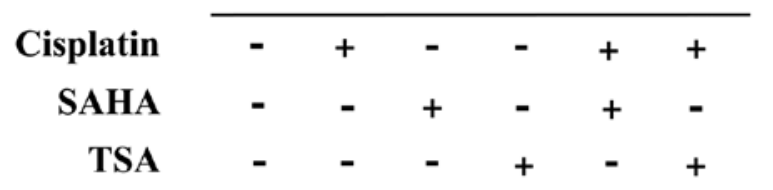

p53

CDK4

p21

Bcl-2

及-actin
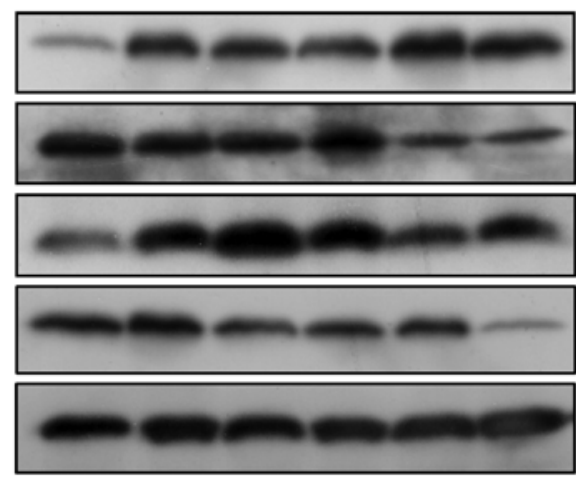

B
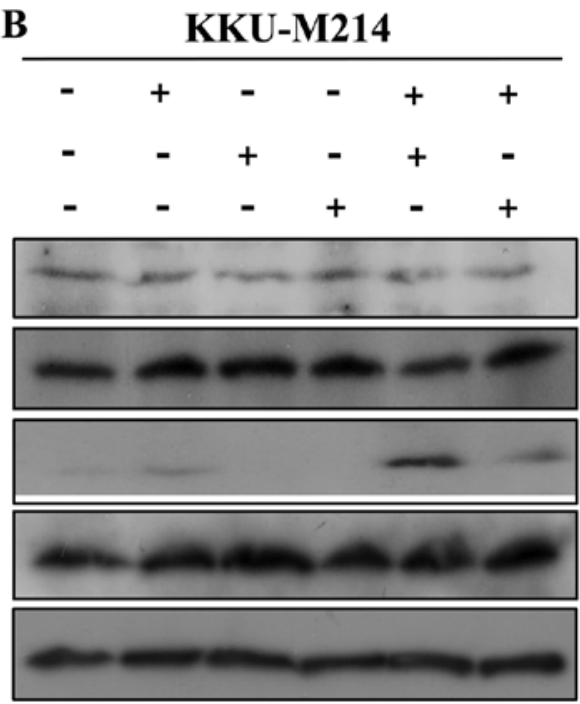

C

KKU-100

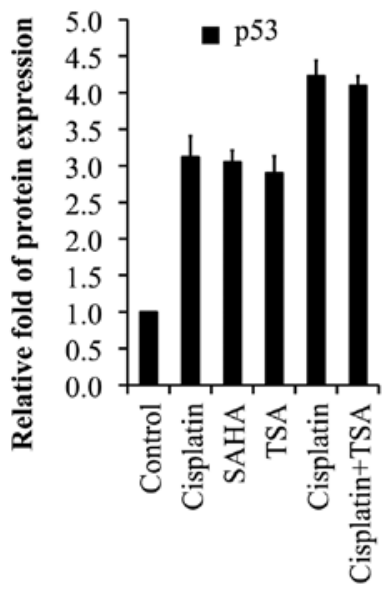

D

KKU-M214

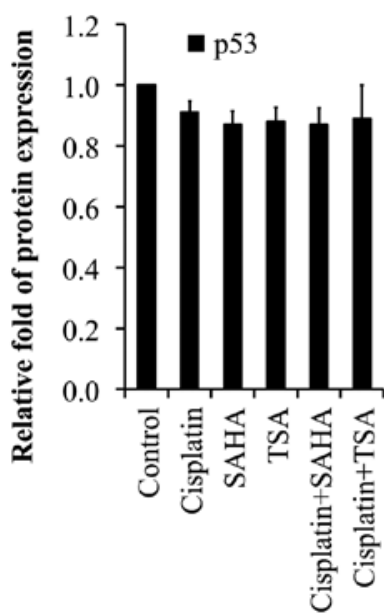

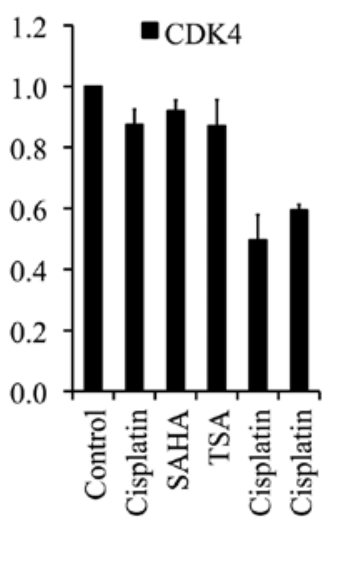

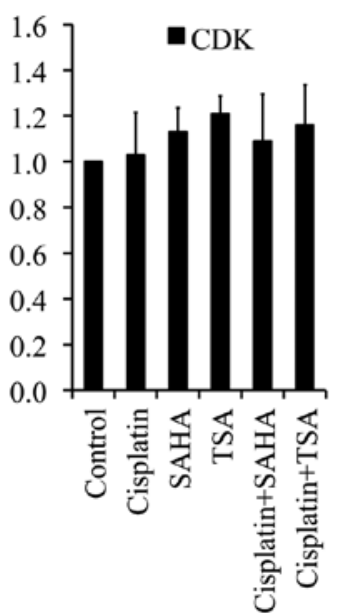

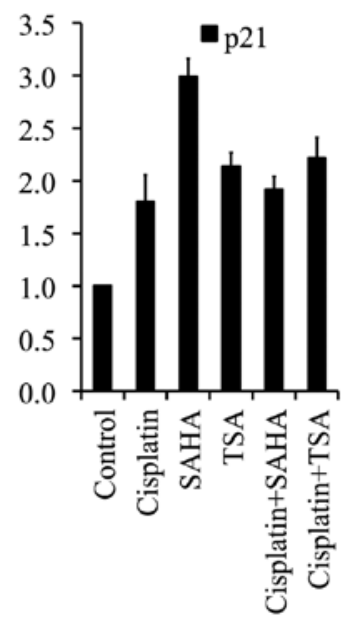
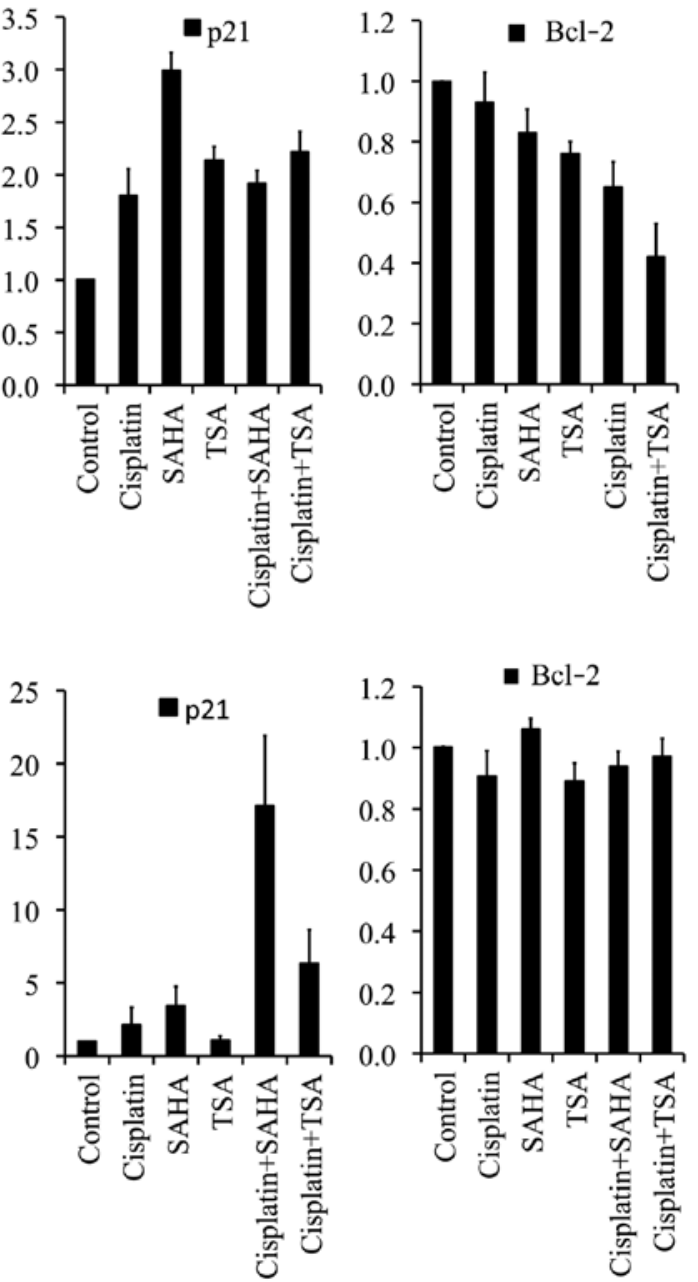

Figure 5. Effect of cisplatin, SAHA and TSA alone or in combination on cell cycle and apoptosis regulatory proteins in (A) KKU-100 and (B) KKU-M214 cells. Cells were treated with DMSO $(0.5 \%)$ as a control, cisplatin $(10 \mu \mathrm{M})$, SAHA $(1.5 \mu \mathrm{M})$ and TSA $(400 \mathrm{nM})$ alone or in combination for $24 \mathrm{~h}$. After $24 \mathrm{~h}$, cells were harvested and proteins were extracted and separated on SDS-PAGE. Expression of p53, p21, CDK4 and Bcl-2 were detected by immunoblotting. $\beta$-actin was used as a loading control in western blot analysis. The intensity of protein bands was quantitated by densitometric analysis. The bar graphs represent relative fold of protein (p53, p21, CDK4 and Bcl-2) expression in (C) KKU-100 and (D) KKU-M214 cells compared with internal control.

With the sequel to synergistic interaction, $>2$-fold dose reduction (DR) was observed for each agent in the drug combination to produce the same effects as the single agent. Our findings are consistent with several studies that documented additive to synergistic interactions between HDACIs and a variety of anticancer drugs including DNA damaging and covalently 
DNA modifying agents (30). The simultaneous use of SAHA and cisplatin led to synergistic cytotoxic interaction for a wide range of concentrations in platinum-resistant OVCAR-3 and SKOV-3 cells, resulting in $>2$-fold dose reductions of both compounds for $50 \%$ cell killing (28). A strong synergistic antitumor effect between cisplatin and TSA resulted in 3.5- and 4.9-fold dose reduction in cisplatin and TSA, respectively, in cisplatin resistant human bladder cancer cell line T24R2 (31).

Efficacious cancer cell killing and better tolerance to normal cells should be the prime focus on designing a better combinative chemotherapeutic regimen in cancer therapy. Previous studies indicated that the enhanced anticancer efficacy and reduced cytotoxicity to normal cells may be achieved by combinative chemotherapy of cisplatin and HDACIs $(25,28)$. Evaluating cytotoxic effects on non-cancer H69 cells justified the rationale of cisplatin and HDACIs as the combination of the highest sub-toxic doses used against KKU-100 and KKU-M214 cells for each agent did not produce as much profound cytotoxic effect as on cancer cells. Our findings on cytotoxicity corroborate many earlier findings that non-cancer cells are almost always considerably more resistant to SAHA $(32)$ and TSA $(14,22)$ in comparison to cancer cells.

When attempts were made to explore the mechanisms of increased cytotoxicity by combination, it was revealed that combination of cisplatin and HDACIs produced different effects on cell cycle profiles with respect to cell lines. In KKU-100 cells, cisplatin, SAHA and TSA alone showed perturbation of cell cycle progress at G0/G1 phase. When cisplatin and HDACIs were used in combination, there were more sub-G1 than either drug alone indicating that combined effects drive cells to undergo apoptosis or other form of cell death. In addition, more percentage of cells at G0/G1 phase reflecting growth arrest was also found with cisplatin and HDACIs combination when compared with control. Nonetheless, the treatment with cisplatin and HDACIs alone or in combination increased only sub-G1 percent without affecting any particular phase of cell cycle in KKU-M214 cells. Cisplatin was demonstrated to block cell cycle progression at G1 phase with concomitant reduction in S phase population in non-small cell lung cancer cells (33). HDACIs were also found to induce G0/G1 and G2/M arrest in several cancer cell lines. It was reported that TSA caused significant inhibition of cell proliferation accompanied by G0/G1 arrest in the human hepatoma cell lines HepG2 and Huh-7 in vitro (34). SAHA inhibited the growth of chondrosarcoma cell lines RCS and OUMS-27 by causing G1/S arrest in RCS, G2/M arrest in OUMS-27 cells (35). In addition, an increase in the percentage of cells in the $\mathrm{G} 0 / \mathrm{G} 1$ phase was seen for squamous cell carcinoma HSC-3 cells when cisplatin alone and in combination with HDAC inhibitors was used (5). However, it has also been observed that net effect of concurrent use of cisplatin and SAHA occurred independently of cell cycle arrest in ovarian cancer cell lines as neither cell line displayed any significant perturbations of $\mathrm{G} 1$ or $\mathrm{G} 2 / \mathrm{M}$ phases of the cell cycle (28). This observation is in agreement with ours in the case of KKU-M214 cells.

Many studies have evidenced that cisplatin can induce inhibition of cancer cells by producing cell cycle arrest and apoptosis (4). Furthermore, studies bearing the testimony of apoptosis induction by HDACIs were documented previously. TSA was reported to cause apoptotic cell death in gastric and oral cancer cell lines (36) and in non-small cell lung cancer cells (22). SAHA was demonstrated to inhibit the growth of chondrosarcoma cell line SW1353 by inducing apoptosis (35). A considerable amount of evidence suggests that cytotoxic cell killing of cisplatin in various cancer cell lines was modulated by HDACIs in additive or synergistic manner. Previous studies have demonstrated that co-administration of cisplatin with SAHA resulted in synergistic induction of cytotoxicity and apoptosis in OSCC cells $(25,26)$. The enhanced chemosensitization in OSCC cells was attributed to synergistic apoptotic effects between SAHA and cisplatin $(5,24)$. Concurrent SAHA and cisplatin therapy resulted in a significant increase in the percentage of apoptotic cells in OVCAR-3 and SKOV-3 cells (28). A very recent study reported that HDACIs (SAHA and TSA) inhibited growth of SCCHN cell lines along with apoptosis and cell cycle (G0/G1 and/or G2/M phase) arrest (37). It has also been demonstrated that combination of SAHA or TSA with cisplatin had synergistic cytotoxic effects in SCCHN cell lines. Our present findings regarding apoptosis induction comply with earlier research. As evidenced in FACS analysis, CCA cells treated with combination of cisplatin and HDACIs (SAHA and TSA) underwent significantly more apoptosis than single agent treated cells consistent with more significant cytotoxicity from our MTT assay. However, cisplatin and HDACIs alone also produced significantly increased apoptosis as compared with solvent control. As HDACs have many histone and non-histone substrates and acetylation status of these proteins varies in cancer cell types, cancer cell lines may respond differently to individual HDACIs. These may explain, in part, the differential cell killing response in different combinations as we observed more KKU-M214 cell death in cisplatin/SAHA combination and cisplatin/TSA combination in KKU-100 cells. There are controversial reports indicating that pan-HDACIs with low doses have modulating effects on induction of autophagy in some cancer cells $(21,35)$, indicating that autophagy induction depends on cellular model and HDACIs used. In addition, low doses of HDACIs can cause cell cycle arrest at G0/G1 phase. For example, at low doses of HDACIs, KKU-100 cells underwent both apoptosis (Fig. 4A and C) and cell cycle arrest (Fig. 3A). However, other cell death mechanisms such as autophagy and necrosis may also underpin the death of KKU-M214 cells. Our statement is in compliance with previously mentioned report that at least two cell death mechanisms, apoptosis and probably necrosis, are involved in the sensitization of HDACIs to anticancer drugs (27).

Activation of $\mathrm{p} 53$ protein plays a crucial role in the control of tumor cell response to chemotherapeutic agents and DNA-damaging agents by regulating DNA damage repair, cell cycle arrest and apoptosis (38). p21 and Bcl-2 are downstream effectors of p53 which dictate the cell cycle events and apoptosis of cells. The induction of $\mathrm{p} 21 \mathrm{waf} 1 / \mathrm{cip} 1$ arrests cells at the G1 phase of the cell cycle through blocking cyclin-dependent kinase (CDK4) activity. In this study, the expression of p21 was induced through p53-dependent mechanism for cisplatin, SAHA and TSA in KKU-100. Combination of cisplatin and HDACIs increased p21 expression when compared with control, supporting the G0/G1 cell cycle arrest. Cell cycle regulatory protein CDK4 was downregulated by cisplatin, SAHA, and TSA alone or in combination in KKU-100 
cells. However, expression of p53 and cell cycle regulatory protein CDK4 was not affected with either drug treatment in KKU-M214 cells while p21 was increased for combination treatment. In line with our findings, low dose cisplatin increased p53 and p21WAF1/CIP1 expression in hepatoma cells, leading to apoptosis and cell cycle arrest at G1 phase in hepatoma cells via both p53-dependent and -independent pathways (39). Recent reports indicate that HDACI-induced apoptosis in cancer cells may or may not be mediated by p53 $(40,41)$. SAHA has induced G2/M cell cycle arrest in pancreatic cancer cells where it upregulated the expression of p21 (42). Enhanced expression of p21 after TSA exposure may deter cell growth of gastric and oral carcinoma cells (36). SAHA significantly inhibited growth of ESCC tumors with decreased expression of CDK4 and increased expression of p21 (43). It has been mentioned that p53 has been found to play a functional role in SAHA-mediated sensitization to cisplatin against OSCC cancer cells (25). This study revealed that the expression of anti-apoptotic protein $\mathrm{Bcl}-2$ decreased in KKU-100 cells upon exposure to combination therapy and single agents whereas it was not changed in KKU-M214 cells. The induction of apoptosis by single agent and combination may be through extrinsic pathway not involving p53 and $\mathrm{Bcl}-2$ proteins in KKU-M214. Consistent with our results, a significant decrease in Bcl-2 was observed in TAMR/MCF-7 after exposure to SAHA (21). Additionally, TSA decreased the expression of the anti-apoptotic proteins Bcl-2 in HCT116 and HT29 cells (44). However, level of anti-apoptotic protein Bcl-2 did not change in either LNCaP or DU145 cells following treatments with single agents or combinations of retinoids and HDAC-inhibitors, despite the initiation of apoptosis (45). The expression of $\mathrm{Bcl}-2$ protein remained essentially unchanged in ovarian cancer cells treated with TSA (41). Although expression of p53 and p21 proteins varied in KKU-100 and KKU-M214 cell lines, the apoptosis percentage did not alter. Perhaps, this is because different cell lines may adopt different cell death mechanisms. We can deduce that KKU-100 cells may undergo apoptosis via intrinsic pathway which can also be explained by decrease in anti-apoptotic Bcl-2 protein while KKU-M214 may prefer other apoptosis pathways (such as stress-induced and/or extrinsic).

In conclusion, the anticancer activities of cisplatin and HDACIs combinations against CCA cell lines were synergistic in nature. The mechanisms of cytotoxic potentiation were different for these two cellular models. Both apoptosis and cell cycle arrest contributed to growth inhibition of CCA cells where p53-dependent mitochondrial pathway, cell cycle arrest and p53-independent pathway were involved. The combination may improve the therapeutic efficiency and create an avenue to effective treatment of CCA with minimum side effects. Further research to delineate the more detail molecular mechanism(s) of action of cisplatin, HDACIs and their combination is needed to optimize chemotherapeutic approach for cancer patients.

\section{Acknowledgements}

This study was supported by the National Research Council of Thailand (through Khon Kaen University, fiscal year 2014-2015). We acknowledge Faculty of Science, Khon Kaen University, Thailand for providing a graduate scholarship to Md. Ali Asgar.

\section{References}

1. Sawanyawisuth K: Genes and cholangiocarcinoma. Southeast Asian J Trop Med Public Health 40: 701-712, 2009.

2. Thongprasert S: The role of chemotherapy in cholangiocarcinoma. Ann Oncol 16 (Suppl 2): ii93-ii96, 2005.

3. Douillard JY, Eckardt J and Scagliotti GV: Challenging the platinum combinations in the chemotherapy of NSCLC. Lung Cancer 38 (Suppl 4): 21-28, 2002.

4. Siddik ZH: Cisplatin: Mode of cytotoxic action and molecular basis of resistance. Oncogene 22: 7265-7279, 2003.

5. Sato T, Suzuki M, Sato Y, Echigo S and Rikiishi H: Sequencedependent interaction between cisplatin and histone deacetylase inhibitors in human oral squamous cell carcinoma cells. Int $\mathrm{J}$ Oncol 28: 1233-1241, 2006.

6. Fava G and Lorenzini I: Molecular pathogenesis of cholangiocarcinoma. Int J Hepatol 2012: 630543, 2012.

7. Mai A, Massa S, Rotili D, Cerbara I, Valente S, Pezzi R, Simeoni S and Ragno R: Histone deacetylation in epigenetics: An attractive target for anticancer therapy. Med Res Rev 25: 261-309, 2005.

8. Kristeleit R, Stimson L, Workman P and Aherne W: Histone modification enzymes: Novel targets for cancer drugs. Expert Opin Emerg Drugs 9: 135-154, 2004.

9. Luong QT, O'Kelly J, Braunstein GD, Hershman JM and Koeffler HP: Antitumor activity of suberoylanilide hydroxamic acid against thyroid cancer cell lines in vitro and in vivo. Clin Cancer Res 12: 5570-5577, 2006.

10. Kelly WK, Richon VM, O'Connor O, Curley T, MacGregor-Curtelli B, Tong W, Klang M, Schwartz L, Richardson S, Rosa E, et al: Phase I clinical trial of histone deacetylase inhibitor: Suberoylanilide hydroxamic acid administered intravenously. Clin Cancer Res 9: 3578-3588, 2003.

11. Duvic M and Vu J: Vorinostat: A new oral histone deacetylase inhibitor approved for cutaneous T-cell lymphoma. Expert Opin Investig Drugs 16: 1111-1120, 2007.

12. Jain $\mathrm{S}$ and Zain J: Romidepsin in the treatment of cutaneous T-cell lymphoma. J Blood Med 2: 37-47, 2011.

13. Kim YB, Ki SW, Yoshida M and Horinouchi S: Mechanism of cell cycle arrest caused by histone deacetylase inhibitors in human carcinoma cells. J Antibiot (Tokyo) 53: 1191-1200, 2000.

14. Chang J, Varghese DS, Gillam MC, Peyton M, Modi B Schiltz RL, Girard L and Martinez ED: Differential response of cancer cells to HDAC inhibitors trichostatin A and depsipeptide. Br J Cancer 106: 116-125, 2012.

15. Takai $\mathrm{N}$ and Narahara H: Preclinical studies of chemotherapy using histone deacetylase inhibitors in endometrial cancer. Obstet Gynecol Int 2010: 923824, 2010.

16. Richon VM, Webb Y, Merger R, Sheppard T, Jursic B, Ngo L, Civoli F, Breslow R, Rifkind RA and Marks PA: Second generation hybrid polar compounds are potent inducers of transformed cell differentiation. Proc Natl Acad Sci USA 93: 5705-5708, 1996.

17. Diyabalanage HVK, Granda ML and Hooker JM: Combination therapy: Histone deacetylase inhibitors and platinum-based chemotherapeutics for cancer. Cancer Lett 329: 1-8, 2013.

18. Senawong T, Misuna S, Khaopha S, Nuchadomrong S, Sawatsitang P, Phaosiri C, Surapaitoon A and Sripa B: Histone deacetylase (HDAC) inhibitory and antiproliferative activities of phenolic-rich extracts derived from the rhizome of Hydnophytum formicarum Jack.: Sinapinic acid acts as HDAC inhibitor. BMC Complement Altern Med 13: 232, 2013.

19. Chou TC and Talalay P: Quantitative analysis of dose-effect relationships: The combined effects of multiple drugs or enzyme inhibitors. Adv Enzyme Regul 22: 27-55, 1984.

20. Chou TC: Theoretical basis, experimental design, and computerized simulation of synergism and antagonism in drug combination studies. Pharmacol Rev 58: 621-681, 2006.

21. Lee YJ, Won AJ, Lee J, Jung JH, Yoon S, Lee BM and Kim HS: Molecular mechanism of SAHA on regulation of autophagic cell death in tamoxifen-resistant MCF-7 breast cancer cells. Int J Med Sci 9: 881-893, 2012.

22. Mukhopadhyay NK, Weisberg E, Gilchrist D, Bueno R, Sugarbaker DJ and Jaklitsch MT: Effectiveness of trichostatin A as a potential candidate for anticancer therapy in non-small-cell lung cancer. Ann Thorac Surg 81: 1034-1042, 2006.

23. Dalgard CL, Van Quill KR and O'Brien JM: Evaluation of the in vitro and in vivo antitumor activity of histone deacetylase inhibitors for the therapy of retinoblastoma. Clin Cancer Res 14: 3113-3123, 2008. 
24. Rikiishi H, Shinohara F, Sato T, Sato Y, Suzuki M and Echigo S: Chemosensitization of oral squamous cell carcinoma cells to cisplatin by histone deacetylase inhibitor, suberoylanilide hydroxamic acid. Int J Oncol 30: 1181-1188, 2007.

25. Shen J, Huang C, Jiang L, Gao F, Wang Z, Zhang Y, Bai J, Zhou $\mathrm{H}$ and Chen Q: Enhancement of cisplatin induced apoptosis by suberoylanilide hydroxamic acid in human oral squamous cell carcinoma cell lines. Biochem Pharmacol 73: 1901-1909, 2007.

26. Suzuki M, Endo M, Shinohara F, Echigo S and Rikiishi $\mathrm{H}$. Enhancement of cisplatin cytotoxicity by SAHA involves endoplasmic reticulum stress-mediated apoptosis in oral squamous cell carcinoma cells. Cancer Chemother Pharmacol 64: 1115-1122, 2009.

27. Kim MS, Blake M, Baek JH, Kohlhagen G, Pommier Y and Carrier F: Inhibition of histone deacetylase increases cytotoxicity to anticancer drugs targeting DNA. Cancer Res 63: 7291-7300, 2003.

28. Ong PS, Wang XQ, Lin HS, Chan SY and Ho PC: Synergistic effects of suberoylanilide hydroxamic acid combined with cisplatin causing cell cycle arrest independent apoptosis in platinum-resistant ovarian cancer cells. Int J Oncol 40: 1705-1713, 2012.

29. Ozaki K, Kishikawa F, Tanaka M, Sakamoto T, Tanimura S and Kohno M: Histone deacetylase inhibitors enhance the chemosensitivity of tumor cells with cross-resistance to a wide range of DNA-damaging drugs. Cancer Sci 99: 376-384, 2008.

30. Stiborová M, Eckschlager T, Poljaková J, Hraběta J, Adam V, Kizek R and Frei E: The synergistic effects of DNA-targeted chemotherapeutics and histone deacetylase inhibitors as therapeutic strategies for cancer treatment. Curr Med Chem 19: 4218-4238, 2012.

31. Yoon CY, Park MJ, Lee JS, Lee SC, Oh JJ, Park H, Chung CW, Abdullajanov MM, Jeong SJ, Hong SK, et al: The histone deacetylase inhibitor trichostatin A synergistically resensitizes a cisplatin resistant human bladder cancer cell line. J Urol 185 1102-1111, 2011

32. Hess-Stumpp H: Histone deacetylase inhibitors and cancer: From cell biology to the clinic. Eur J Cell Biol 84: 109-121, 2005.

33. Wang G, Reed E and Li QQ: Molecular basis of cellular response to cisplatin chemotherapy in non-small cell lung cancer (Review). Oncol Rep 12: 955-965, 2004.

34. Yamashita Y, Shimada M, Harimoto N, Rikimaru T, Shirabe K, Tanaka S and Sugimachi K: Histone deacetylase inhibitor trichostatin A induces cell-cycle arrest/apoptosis and hepatocyte differentiation in human hepatoma cells. Int J Cancer 103 $572-576,2003$

35. Yamamoto $S$, Tanaka K, Sakimura R, Okada T, Nakamura T, Li Y, Takasaki M, Nakabeppu Y and Iwamoto Y: Suberoylanilide hydroxamic acid (SAHA) induces apoptosis or autophagyassociated cell death in chondrosarcoma cell lines. Anticancer Res 28: 1585-1591, 2008 .
36. Suzuki T, Yokozaki H, Kuniyasu H, Hayashi K, Naka K, Ono S, Ishikawa T, Tahara E and Yasui W: Effect of trichostatin A on cell growth and expression of cell cycle- and apoptosis-related molecules in human gastric and oral carcinoma cell lines. Int J Cancer 88: 992-997, 2000.

37. Chikamatsu K, Ishii H, Murata T, Sakakura K, Shino M, Toyoda M, Takahashi K and Masuyama K: Alteration of cancer stem cell-like phenotype by histone deacetylase inhibitors in squamous cell carcinoma of the head and neck. Cancer Sci 104: 1468-1475, 2013.

38. Taylor WR and Stark GR: Regulation of the G2/M transition by p53. Oncogene 20: 1803-1815, 2001.

39. Qin LF and Ng IOL: Induction of apoptosis by cisplatin and its effect on cell cycle-related proteins and cell cycle changes in hepatoma cells. Cancer Lett 175: 27-38, 2002.

40. Henderson C, Mizzau M, Paroni G, Maestro R, Schneider C and Brancolini C: Role of caspases, Bid, and p53 in the apoptotic response triggered by histone deacetylase inhibitors trichostatin-A (TSA) and suberoylanilide hydroxamic acid (SAHA). J Biol Chem 278: 12579-12589, 2003.

41. Strait KA, Warnick CT, Ford CD, Dabbas B, Hammond EH and Ilstrup SJ: Histone deacetylase inhibitors induce G2-checkpoint arrest and apoptosis in cisplatinum-resistant ovarian cancer cells associated with overexpression of the Bcl-2-related protein Bad. Mol Cancer Ther 4: 603-611, 2005.

42. Kumagai T, Wakimoto N, Yin D, Gery S, Kawamata N, Takai N, Komatsu N, Chumakov A, Imai Y and Koeffler HP: Histone deacetylase inhibitor, suberoylanilide hydroxamic acid (Vorinostat, SAHA) profoundly inhibits the growth of human pancreatic cancer cells. Int J Cancer 121: 656-665, 2007.

43. Tzao C, Jin JS, Chen BH, Chung HY, Chang CC, Hsu TY and Sun GH: Anticancer effects of suberoylanilide hydroxamic acid in esophageal squamous cancer cells in vitro and in vivo. Dis Esophagus 27: 693-702, 2014

44. Meng J, Zhang HH, Zhou CX, Li C, Zhang F and Mei QB: The histone deacetylase inhibitor trichostatin $\mathrm{A}$ induces cell cycle arrest and apoptosis in colorectal cancer cells via p53-dependent and -independent pathways. Oncol Rep 28: 384-388, 2012.

45. Gu J,Zhao X, Spanjaard RA, Chen TC, Flanagan JN, Boosalis M, Perrine SP and Faller DV: Histone deacetylase-inhibitors sensitize human prostate cancer cell lines to growth suppression and apoptosis by retinoids. J Cancer Mol 2: 25-36, 2006. 